\title{
PERFORMANCE EVALUATION OF SWIRL FLOW SOLAR AIR HEATER
}

\author{
Mahmoud. A. Kassem ${ }^{1}$ and Mohamed. A. Kassem ${ }^{2}$
}

\section{ABSTRACT}

The objective of the present study is to evaluate the performance of a new design of solar air heater. In the new design, the air is swirled by using twisted-tape insert in the air passage. Initially, the heat transfer and pressure drop for swirled flow has been tested in order to identify the optimum tape twist ratio which satisfies a maximum heat transfer coefficient, with accepted value of air pressure drop. The proposed air heater was compared with the conventional air heater under the same operating conditions. The results show that the proposed air heater is superior - instantaneous and daily bases- in energy output, efficiency and exit-air temperature.

Keywords: Solar, Air heater, Performance, Twisted-tape, Enhancement.

\section{INTRODUCTION}

The thermal energy has wide applications in human life. It can be generally utilized in form of either low grade (low temperature) or

1 high grade (high temperature), (Arind et al., 2006). One of the applications of thermal energy at low temperature is the drying of agriculture crops. Solar energy is welcome in agriculture crops drying to reduce the environmental pollution and running cost.

Many pervious studies were dedicated to improvement of thermal performance of non-focusing solar heaters. A method to achieve this goal may be by enhancing the heat transfer from the absorber plate to the working fluid. (Abdulla et al., 2000) studied the fluidized bed solar water heater. They found that fluidized bed solar water heater has thermal efficiency greater than that for ordinary flat plate solar collector. In the same time, fluidized bed solar water heater has a penalty of higher fluid flow pressure drop.

${ }^{1}$ Mechanical Power Eng. Dept., Fac. of Eng., Cairo U., Cairo, Egypt. mahmoudkassem@yahoo.com

${ }^{2}$ Ag. Eng. Dept., Fac. of Ag., Cairo U., Cairo, Egypt 
The main disadvantage of the fluidized solar water heater is that: fluidization is not achieved at low water velocities and low collector tilt angle. Some other studies Arind et al. (2006), Lertsatitthanakorn et al. (2008) and Swapnil et al. (2008) were concerned with hybrid solar system -photo voltaic/ thermal- as a method to improve the solar system efficiency.

This work presents a proposed novel design aiming to increase the absorber- fluid heat transfer coefficient. This is accomplished by inserting a twisted tape inside the collector tubes. The twisted tape swirls the flow inside collector tubes and the flow will be multi-dimensional. The fluid turbulence increases and the boundary layer decreases-which increase the absorber-to-fluid heat transfer rate.

\section{THEORETICAL ANALYSIS}

Two solar air heaters are studied in the present work; the first one is the collector with twisted tape inserted inside the fluid tube, while the second is conventional solar collector. The main differences between the two collectors are the coefficients of the heat transfer between the collector and the working fluid and the working fluid pressure drop. The flow inside collector tube may be laminar or turbulent. The absorber is subject to solar radiation from a constant heat flux

\section{Heat Transfer:}

\section{1-1. Heat transfer in swirled tube:}

One method for enhancing the heat transfer between the surfaces and flowing fluid is by using a twisted tape inside the tube (Raj and Bergles 2002). Figure (1) shows a schematic diagram for twisted tape inserted inside tube, the pitch of the twist is " $\mathrm{H}$ " and the twisted tape has thickness of " $\delta$ ".

Many investigators published articles related to the effect of twisted tape insertion on heat transfer and pressure drop such as Watcharin et al. (2006) and Jaisankar et al. (2008). 


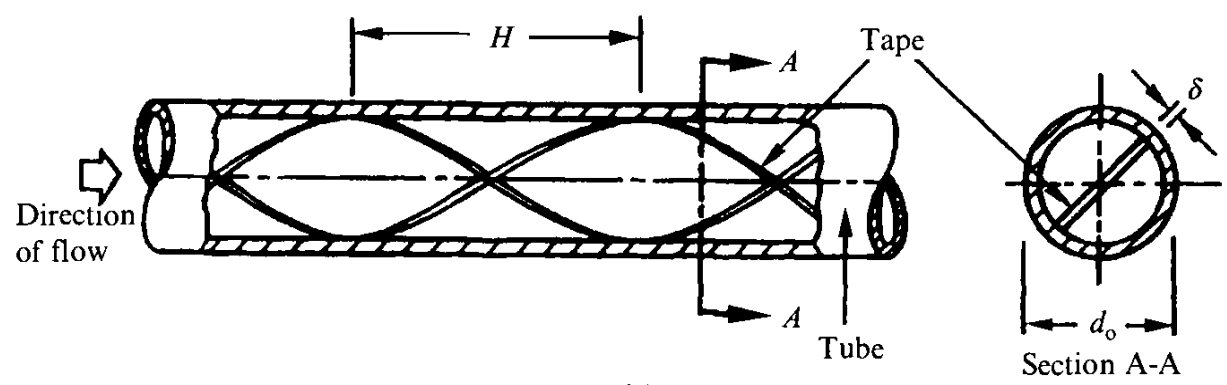

Fig. (1): Schematic diagram for tube with twisted tape.

Hong et al. (1976) suggested the following relation to correlate heat transfer coefficient for laminar flow inside tube equipped with twisted tape subject to uniform heat flux;

$$
\mathrm{Nu}=5.172\left[1+5.484 \times 10^{-3} \operatorname{Pr}^{0.7}\left(\operatorname{Re}_{\mathrm{a}} / \mathrm{y}\right)^{1.25}\right]^{0.5}
$$

Where,

$$
\begin{aligned}
& \operatorname{Re}_{\mathrm{a}}=\left(\mathrm{U}_{\mathrm{a}} \mathrm{d}_{\mathrm{i}} / v\right) \\
& \mathrm{U}_{\mathrm{a}}=\left(\mathrm{m} / \rho \mathrm{A}_{\mathrm{c}}\right) \\
& \mathrm{y}=\left(\mathrm{H} / \mathrm{d}_{\mathrm{i}}\right) \\
& \mathrm{A}_{\mathrm{c}}=\left[\left(\pi \mathrm{d}_{\mathrm{i}}^{2} / 4\right)-\delta \mathrm{d}_{\mathrm{i}}\right]
\end{aligned}
$$

For turbulent flow inside tube equipped with twisted tape, Manglik et al. (1993), suggested the following relation to predict the heat transfer coefficient;

$$
\begin{gathered}
\mathrm{Nu}=0.023 \operatorname{Re}^{0.8} \operatorname{Pr}^{0.4}\left[1+\frac{0.769}{y}\right]\left[\frac{\pi+2-\left(2 \delta / d_{i}\right)}{\pi-\left(4 \delta / d_{i}\right)}\right]^{0.2}\left[\frac{\pi}{\pi-\left(4 \delta / d_{i}\right)}\right]^{0.8} \phi \\
\phi=\left(\mu_{b} / \mu_{w}\right)^{n} \text { and } \mathrm{n}=\left\{\begin{array}{l}
0.18 \text { liquid heating } \\
0.3 \text { liquid cooling }
\end{array}\right.
\end{gathered}
$$

\section{1-2. Heat transfer in plain tube:}

For comparison purposes, the conventional solar air heater is also simulated for the heat transfer coefficient for case of laminar flow inside plain tube subjected to constant heat flux, the following equation is suggested by Kays [in Incropera and Lavine (2005)]

$$
N u=4.36+\frac{0.0668\left(d_{i} / L\right) \operatorname{Re} \operatorname{Pr}}{1+0.04\left[\left(d_{i} / L\right) \operatorname{Re} \operatorname{Pr}\right]^{2 / 3}}
$$


In case of turbulent flow inside plain tube exposed to constant heat flux, the formula given by Gnieliski correlation [in Abdulla (1998)] is applicable.

$$
N u=\frac{\frac{f}{8}(\operatorname{Re}-1000) \operatorname{Pr}}{1+1.27\left(\operatorname{Pr}^{2 / 3}-1\right) \sqrt{\frac{f}{8}}}\left(1+\frac{1}{3}\left(\frac{d_{i}}{L}\right)^{1 / 3}\right)
$$

Where, the friction factor $(f)$, is calculated from one of the following relations depending on wither the flow is laminar or turbulent.

For laminar flow

$$
f=\frac{64}{\operatorname{Re}}
$$

While for turbulent flow, in technically smooth pipes, Petukhow et al. [in Irvane and Hartnett 1970 ] proposed the following equation

$$
f=\left(1.82 \log _{10} \operatorname{Re}-1.64\right)^{-2}
$$

\section{Pressure Drop:}

The fluid flow pressure drop is given as:

$$
\Delta p=f \frac{L}{d_{i}} \frac{\rho u^{2}}{2}
$$

Where, $(f)$ is the friction factor.

\section{2-1. Friction Factor for flow in swirled tube:}

For laminar flow Date and Singham (1972) [in James and Thomas

2002] suggested the following relation for flow friction factor

$$
f=38.4(\operatorname{Re} / \mathrm{y})^{-0.95}, \quad(\mathrm{Re} / \mathrm{y})<100
$$

$f=\left(8.8201+2.1193 \mathrm{y}-0.2108 \mathrm{y}^{2}-0.0069 \mathrm{y}^{3}\right)(\operatorname{Re} / \mathrm{y})^{-0.7},(\operatorname{Re} / \mathrm{y})>100$

For turbulent flow Manglik et al. (1993), suggested the following relation to correlate the flow friction factor;

$$
f=\frac{0.0791}{\operatorname{Re}^{0.25}}\left[1+\frac{2.752}{y^{1.29}}\right]\left[\frac{\pi}{\pi-\left(4 \delta / d_{i}\right)}\right]^{1.75}\left[\frac{\pi+2-\left(2 \delta / d_{i}\right)}{\pi-\left(4 \delta / d_{i}\right)}\right]^{1.25}
$$

\section{2-2. Friction factor for flow inside plain tube:}

The friction factor for smooth plain tube is given as mentioned earlier by equations 10 and 11 . 


\section{Solar Collector Performance:}

The theoretical bases of the flat-plate solar collector thermal performance are well established and available in the literature. Three indices of importance in characterizing the performance are the useful power output, the fluid exit temperature and the collector efficiency. These are given by Duffi et al. (1976) and Elsayed et al. (1986)

$$
\begin{aligned}
& q_{u}^{\prime \prime}=F_{R}\left[q_{a}-U_{L}\left(T_{f_{i}}-T_{a}\right)\right] \\
& T_{f_{o}}=T_{f_{i}}+\frac{q_{u}^{\prime \prime}}{m^{\prime \prime} C_{p}} \\
& \eta_{c}=\frac{q_{u}^{\prime \prime}}{I_{t}}
\end{aligned}
$$

The expected increase in the absorber- to- fluid heat transfer coefficient, due to the insertion of the twisted tapes inside the collector tubes, will affect the heat removal factor $F_{R}$. Thus, it will affect the thermal performance of the collector.

Moreover, the presence of the twisted tapes inside the collector tubes will entail an additional pressure drop. This will reflect on the hydrodynamic performance of the collector.

\section{RESULTS AND DISCUSSION}

\section{Twisted tape:}

Based on the analysis, presented herein above, ASHRAE model, solar angles and the glass - absorber radiation characteristics, a computer program has been coded to execute the necessary computations. The program is used to make a comparison between the proposed, swirled flow collector, and the conventional collector.

The program was prepared in such a general way that it can be used for collector installed at any location, on any day and at any time of the day. Moreover, any type of working fluid can accommodated. As for the swirled flow collector, the program can deal with any tape twist ratio y and thickness $\delta$. Samples of the obtained results are presented in what follows; they are all based on air as the working fluid.

Nusselt number and pressure drop for flow inside tubes equipped with different twisted tapes are compared with plain tube in figures 2 and 3. As 
shown in fig. 2 the tube which equipped with more tight tape has higher Nusselt number. On the other hand, for air velocity higher than $4 \mathrm{~m} / \mathrm{s}$ the tube equipped with tape has a twist ratio equal 3 has fluid flow pressure drop closer to that for the plain tube.

Therefore, all results presented hereinafter will be based on plain tube and tube equipped with twisted tape has a twist ratio equal to three.

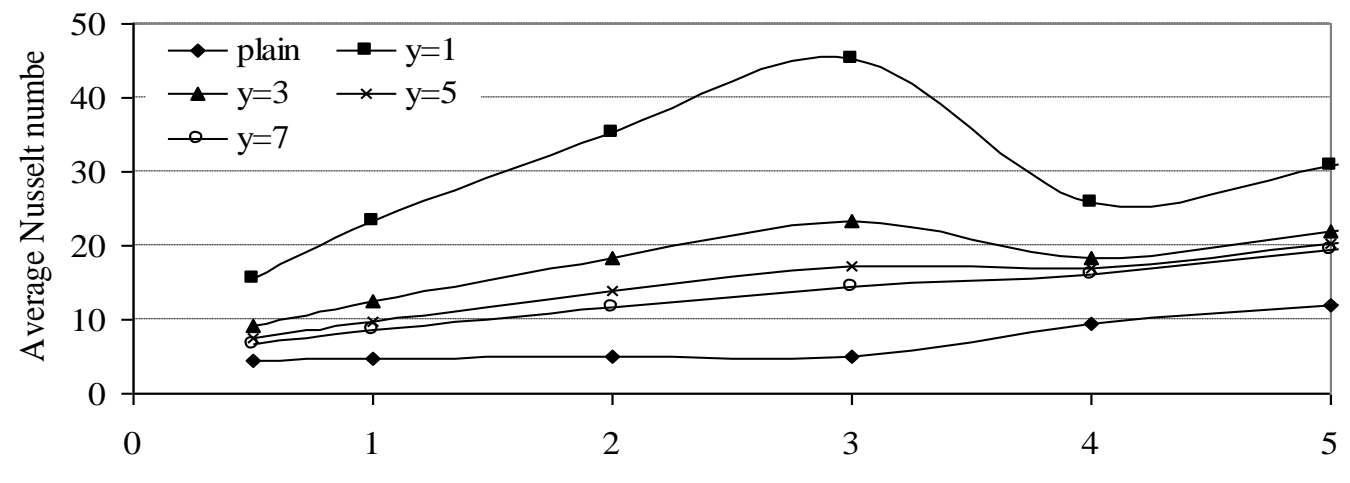

Air velocity, $\mathrm{m} / \mathrm{s}$

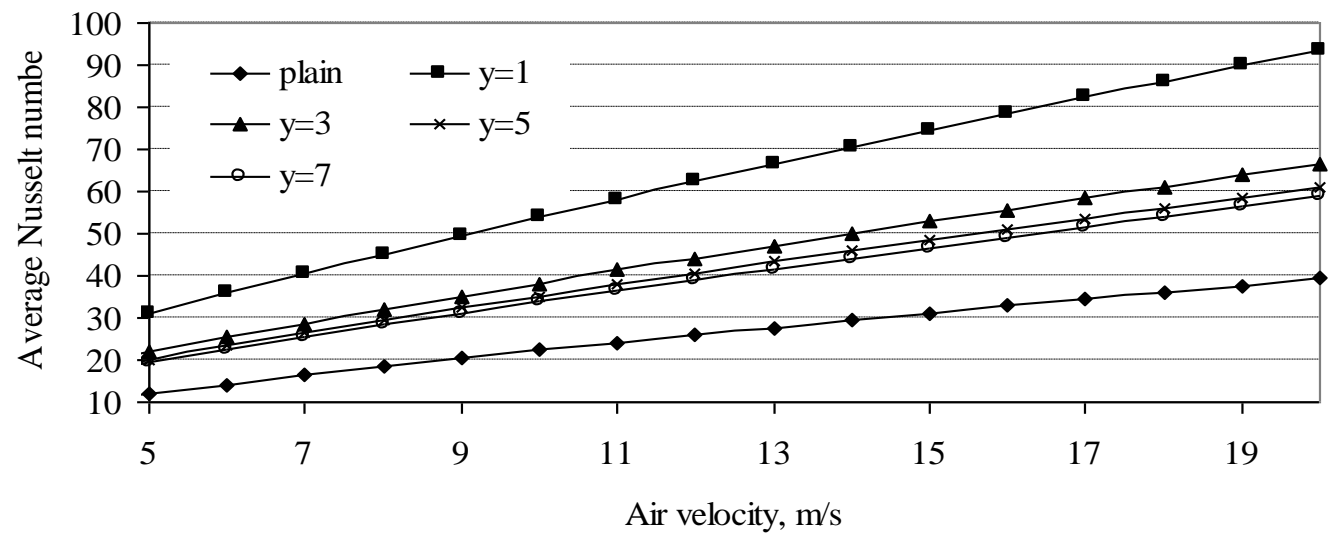

Fig. 2. Variation of Nusselt number with air flow velocity for flow inside plain tube and tube equipped with twisted tape with different twist ratios. Data for $\left(\mathrm{d}_{\mathrm{i}} / \delta\right)=32$ and $\mathrm{t}_{\mathrm{a}}=70{ }^{\circ} \mathrm{C}$ 

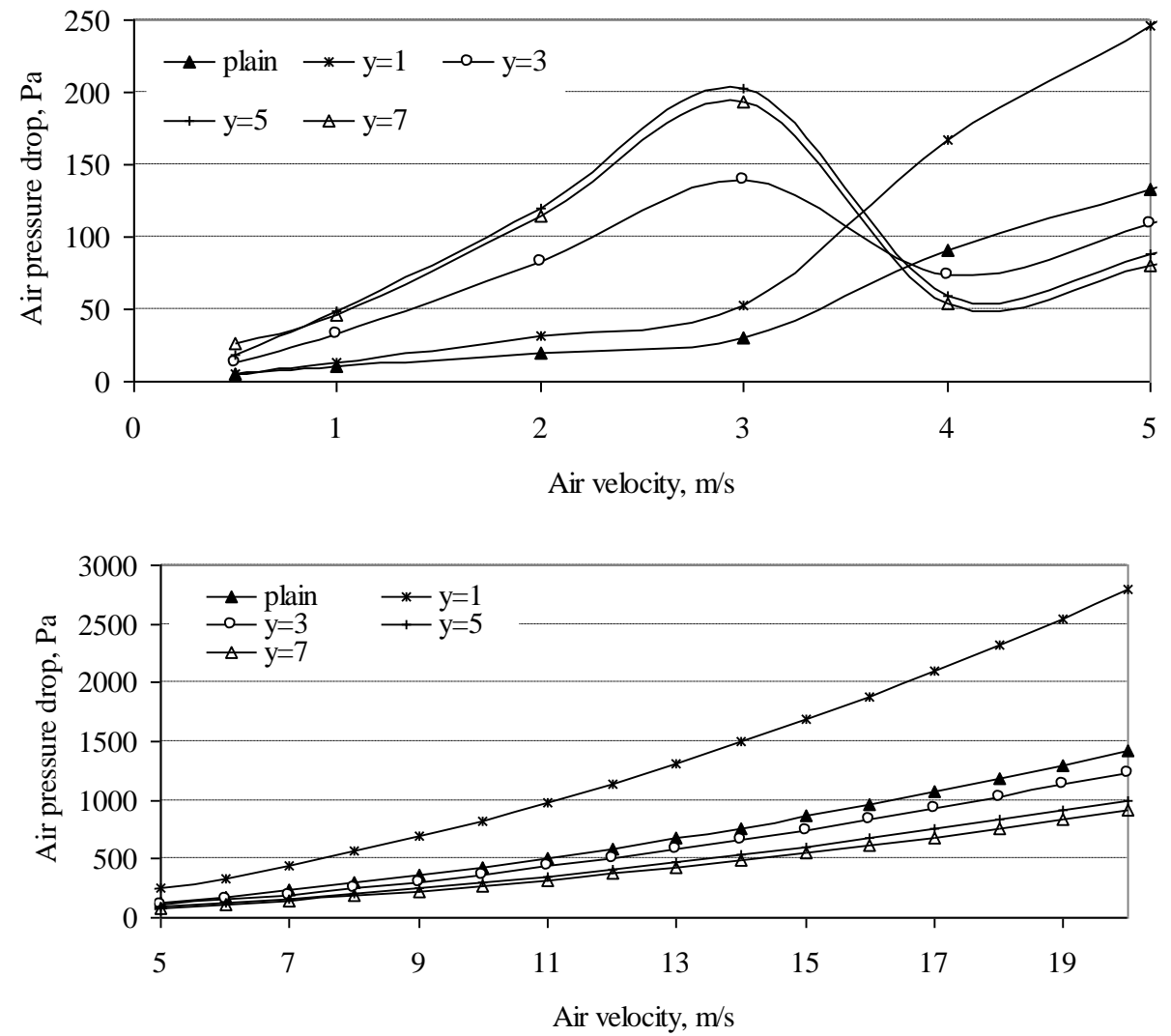

Fig 3. Variation of air pressure drop with air velocity for flow inside plain tube and tube equipped with twisted tape with different twist ratios Data for: $\left(\mathrm{d}_{\mathrm{i}} / \delta\right)=32,\left(\mathrm{~L} / \mathrm{d}_{\mathrm{i}}\right)=125$ and $\mathrm{t}_{\mathrm{a}}=70{ }^{\circ} \mathrm{C}$

\section{Solar-Collector Output:}

The sample results related to the thermal performance of solar collector, and presented hereafter, are all based on the following set of conditions:

- $\quad 30^{\circ}$ North latitude ( Latitude of Cairo)

- Heat transport fluid is air

- Inlet air temperature, $\mathrm{T}_{\mathrm{f}, \mathrm{I}}$

$=300 \mathrm{~K}$

- Ambient air temperature, $\mathrm{T}_{\mathrm{a}}$

$=300 \mathrm{~K}$

- Wind speed

$=5 \mathrm{~m} / \mathrm{s}$

- Collector area $=2 \mathrm{~m}$ length $\mathrm{x} 1 \mathrm{~m}$ width

- Collector facing south 
- Collector tilt angle to the horizontal $\quad=30^{\circ}$

- Number of tubes $\quad=8$

- Tube inner diameter $\quad=16 \mathrm{~mm}$

- Tube outer diameter $\quad=18 \mathrm{~mm}$

- Absorber plate thickness $\quad=1 \mathrm{~mm}$

- Absorber plate thermal conductivity $\quad=386 \mathrm{~W} / \mathrm{m} \mathrm{K}$

- Collector back and side insulation thickness $=50 \mathrm{~mm}$

- Insulation thermal conductivity

$=0.045 \mathrm{~W} / \mathrm{m} \mathrm{K}$

- Number of glass covers $\quad=1$

- Glass cover thickness $\quad=3 \mathrm{~mm}$

- Glass refraction index $\quad=1.526$

- Glass extinction coefficient $\quad=0.00764 \mathrm{~mm}^{-1}$

- Twisted tape thickness $\quad=0.5 \mathrm{~mm}$

- Twisted tape twist ratio, y $=3$.

Figure 4 displays a comparison between the outputs of proposed collector (with tubes equipped with twisted tape of twist ratio equal three) and conventional one. It can be observed that the proposed collector is always superior throughout the whole day. The figure also shows that the proposed collector is superior throughout the year. The figure, also shows that the proposed collector output exceeds the conventional one by more than $16 \%$ at noon. One can refer all the above results to the high heat transfer in case of using twisted tape.

The comparison of the two collectors, under consideration, is further elaborated in figure 5 on a daily- output basis. The figure also, shows the daily energy received by collector's cover. As expected, the swirled flow solar air heater has daily output energy more than the conventional solar air heater. The proposed solar air heater has daily output higher than the conventional one by about $0.46 \mathrm{~kW} . \mathrm{h} / \mathrm{m}^{2}$ daily. The increase in the proposed collector' daily output is due to the high heat transfer coefficient in case of swirled flow. 

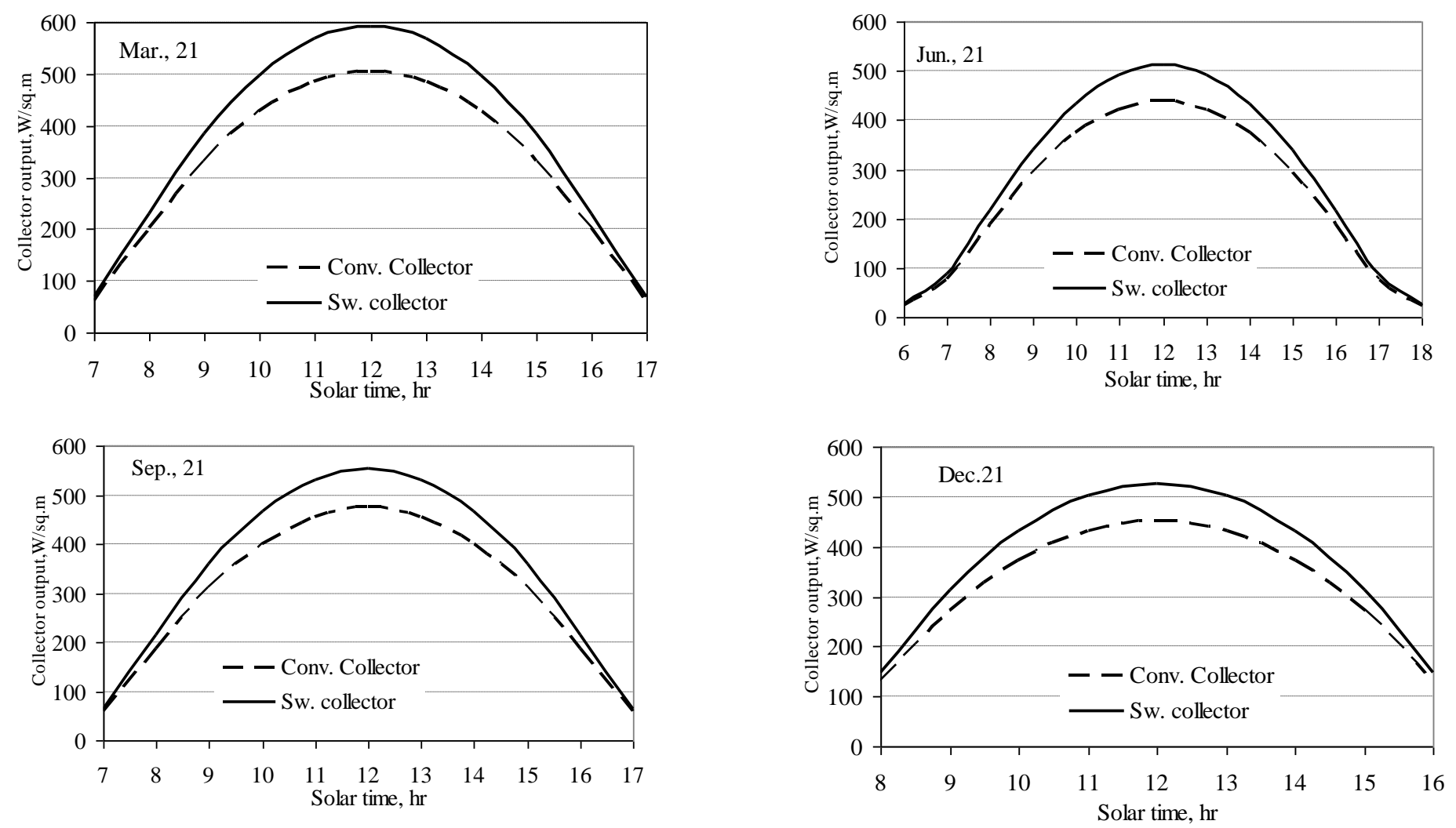

Fig. 4 Chronological variation of the collector output of conventional and swirled flow solar air heaters on different dates. 


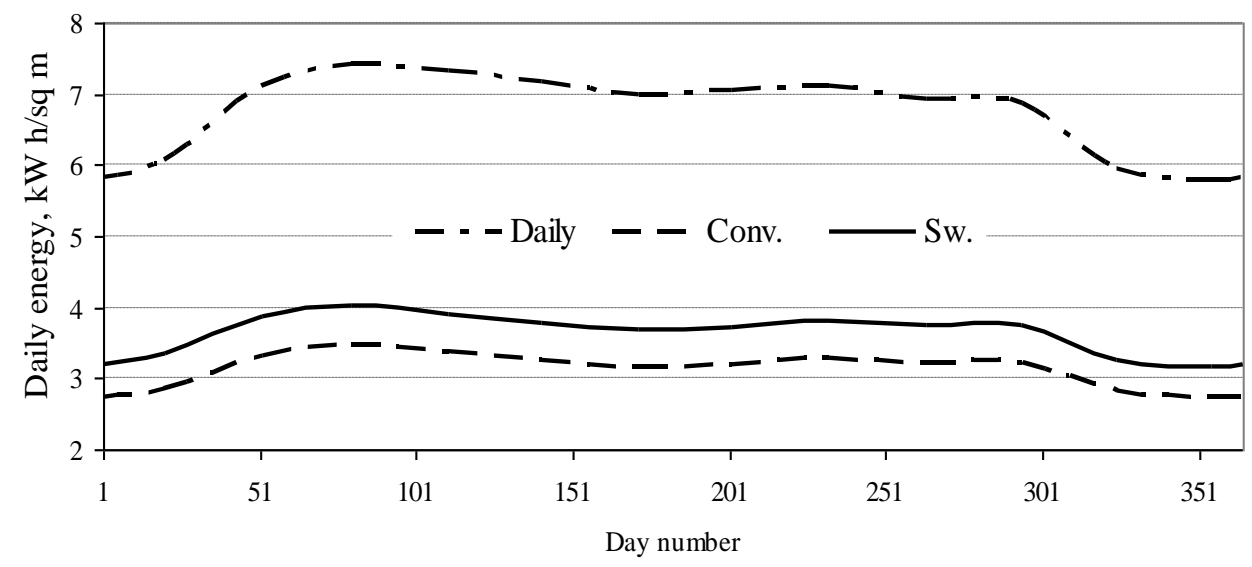

Fig. 5 Variation of daily collector output with date for conventional and swirled flow collectors.

\section{Collector Exit Temperature:}

The collector exit temperature will follow the same behavior of the collector output as can be concluded from equation (17). Figure 6 shows the chronological variation of collector exit temperature for conventional and swirled flow solar air heater for different dates.

The figure shows that the swirled flow collector exit temperature in general exceeds the conventional collector exit temperature by about $6 \mathrm{~K}$ at noon, throughout the year.

The higher heat transfer coefficient in case of swirled flow solar air heater is the main reason for the higher exit temperature.

\section{Collector Efficiency:}

Equation 18 shows that increasing the collector output increases the collector instantaneous efficiency. This means that the swirled flow solar air heater has instantaneous efficiency higher than that for conventional collector.

The chronological variation of collector efficiencies for conventional and swirled flow solar air heater, for different dates is displayed in fig. 7. The figure shows that, at noon, the swirled flow solar air heater has efficiency more than that for conventional collector by about $8 \%$ throughout the year. 

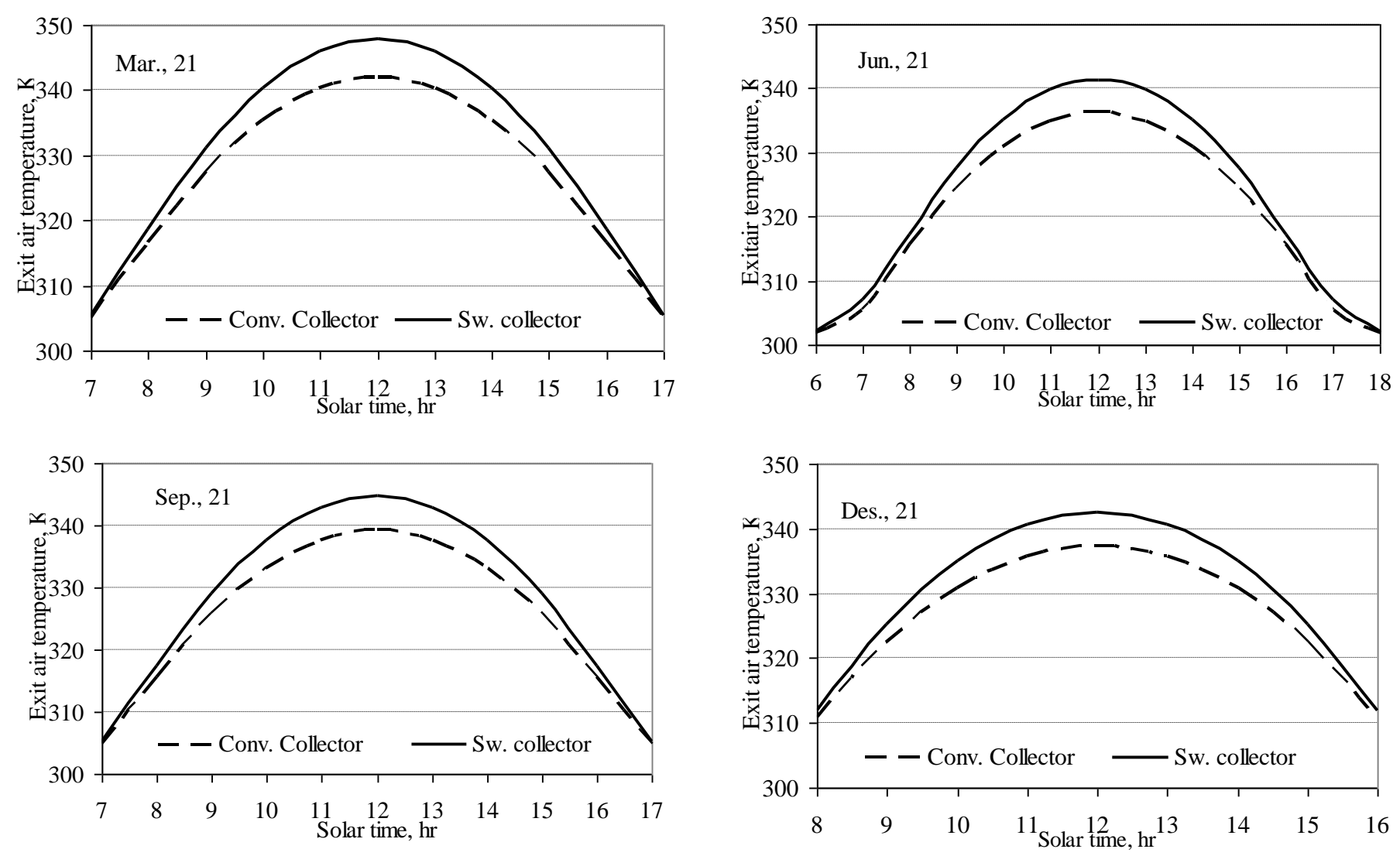

Fig. 6 Chronological variation of exit air temperature from conventional and swirled flow solar air heater for different dates 

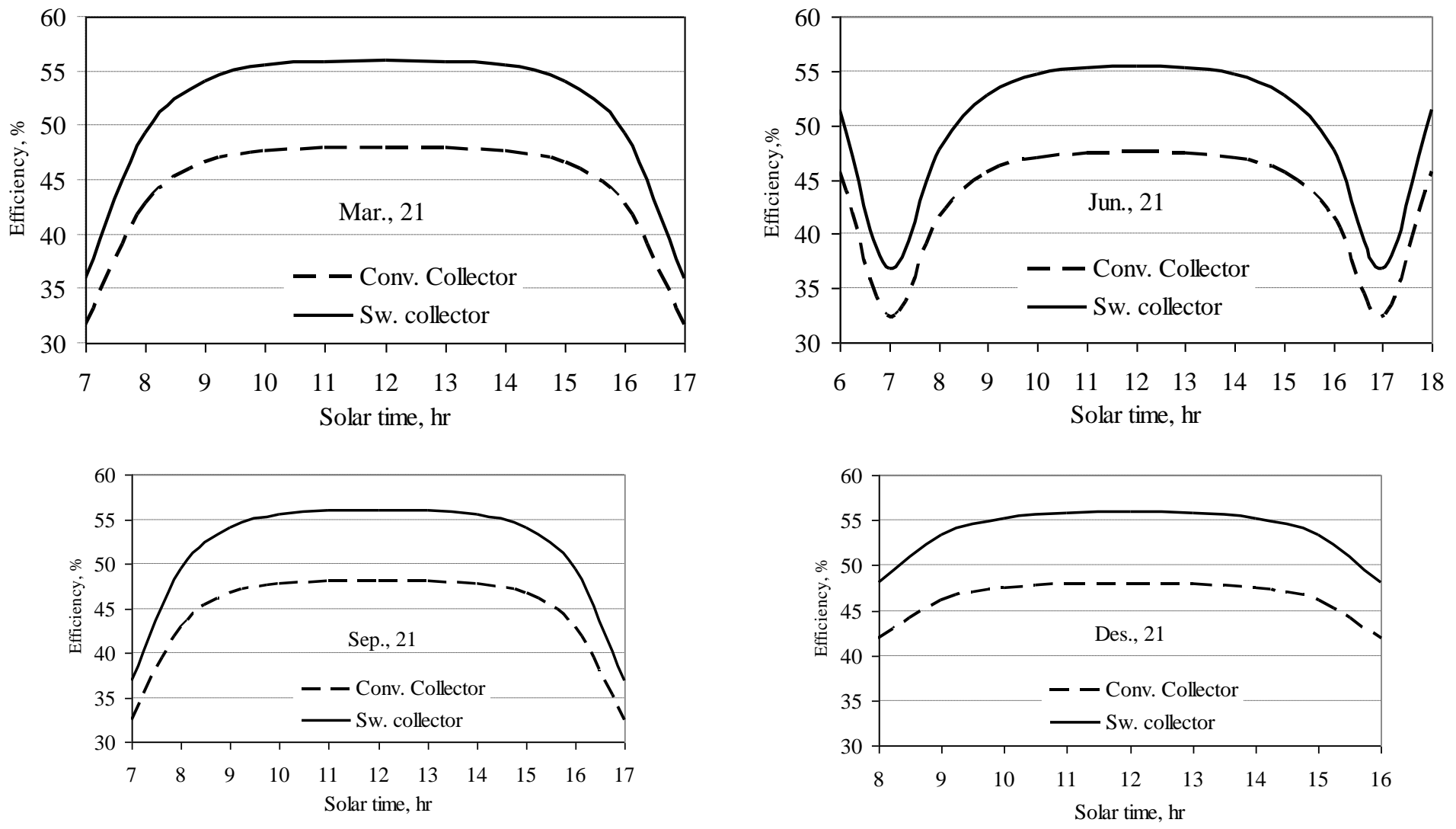

Fig. 7 Chronological variation of the instantaneous efficiencies of conventional and swirled flow solar air heaters on different dates. 
The variation of the collectors daily efficiencies with the date- day number- are shown in figure 8. The figure shows that the swirled flow solar air heater has daily efficiency exceeding the daily efficiency of conventional solar air heater throughout the year. The proposed solar air heater has daily efficiency more than that of the conventional one by about $8 \%$.

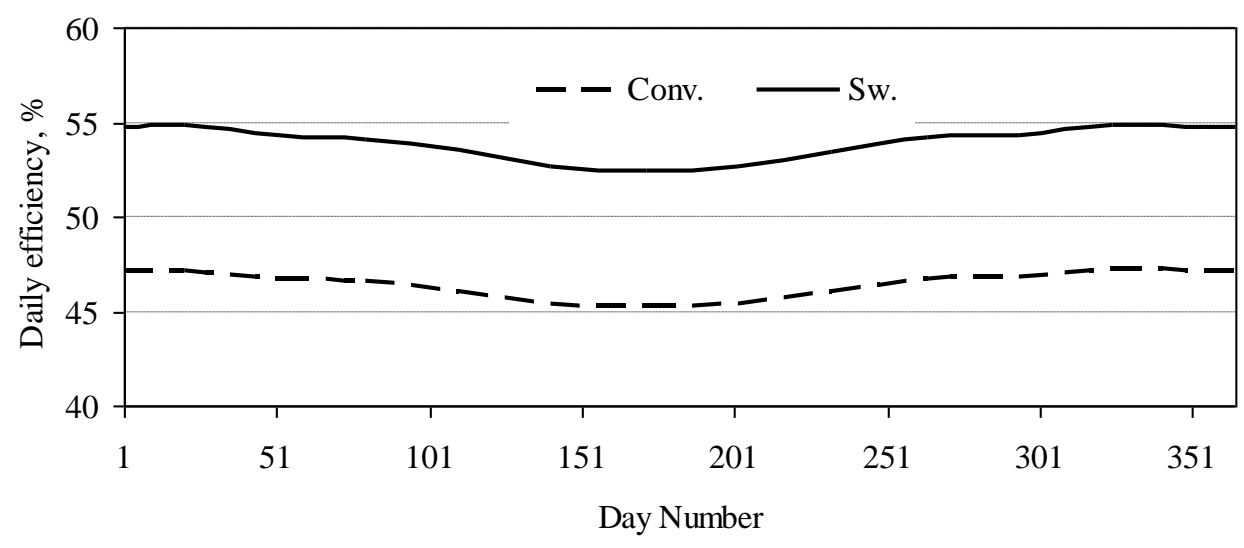

Fig.8 Variation of daily efficiencies with date for conventional and swirled flow collectors.

\section{CONCULOSION}

A novel design of solar air heaters, called "swirled collector", was presented. The insertion of twisted tape within the flow passages was intended to enhance the absorber- to- air heat transfer. The performance of the new proposed collector was theoretically analyzed.

The procedure of evaluating the absorber - to- air heat transfer coefficient was established taking into consideration the tape twist ratio and tape thickness: Then, this was introduced into the equations describing the thermal performance of the collector. Moreover, the pressure drop due to the presence of twisted tape was also quantified to predict the suitable tape twist ratio. A computer program was prepared to execute the lengthy computations.

This program is general and can be used under any set of conditions specified by the numerous variables involved in the problem. A limited 
sample of results, obtained by using this program, was graphically displayed.

The study revealed that the thermal performance of the proposed swirled collector would always be superior to that identical conventional collector operating under the same conditions. In a well-designed swirled collector, the improvement of the thermal performance will be generally associated with air pressure drop nearly similar to the air pressure drop through conventional air heater.

The results showed that the proposed collector in general has efficiency higher than the conventional collector by about $8 \%$ on a daily basis.

\section{REFERENCES}

Abdulla S. H., M. F. El-Refaie and M. A. Kassem. 2000. Theoretical study of fluidized solar collector performance. Proc Millennium Solar Forum, Sept. 17-22: 173-178. Mexico city. Mexico.

Abdulla, S. H. 1998. Theoretical and Experimental study of fluidized solar collector, M. Sc. Thesis, Mechanical Power Engineering Dept., Cairo U., Cairo, Egypt.

Arind T., M. S. Sodha, A. Chandra and J. C. Joshi. 2006. Performance evaluation of photovoltaic thermal solar air collector for composite climate on India," Elsevier, J. Solar Energy materials \& solar cells, 90: 175-189.

Date A. W. and J. R. Singham. 2002. Numerical prediction of friction and heat transfer characteristics of fully developed laminar flow in tubes containing twisted tapes," ASME Paper No. 72- HT-17, ASME, New York.

Duffi, J. A. and W. A. Beckman. 1974. Solar Energy, Thermal Processes. John wiley and Sons, New York, USA.

Elsayed, M. M., S. T. Ibrahim and A. S. Jaffar. 1986. Design of solar thermal systems, Scientific Pub. Center, King Abdulaziz University. Jeddh. Kingdom of Saudi Arabia. 
Hong S. W. and A. E. Bergles. 1976. Augmentation of Laminar Flow Heat Transfer in Tubes by Means of Twisted-Tape inserts. J. Heat transfer vol. 98, pp. 251-256.

Incropera, D. and B. Lavine. 2005. Fundamentals of heat and mass transfer Sixth edition, John Wiley \& sons.

Jaisankar S., T. K. Radhakrishnan, K. N. Sheeba and S. Suresh. 2008. Experimental Studies on Heat Transfer and Friction Factor Characteristics of Thermosyhon Solar Water Heater System Fitted with Left-Right Twisted Tapes", International Journal of Applied Engineering Research, vol. 3.

James P. H. and F. I. Thomas. 2002. Advances in heat transfer Vol. 36 Academic press Elsevier Science, pp 183-286

Lertsatitthanakorn C., N. Khasee, S. Attajariyakul, S. Soponronnarit, A. Therdyothin and R. O. Suzuki, 2008. Performance Analysis of Double-pass Thermoelectric Solar Air Collector. Journal of Solar Energy materials and solar cells, Vol. 92 Issue 9, Sep. 2008, pp. 1105-1109.

Manglik R. M., and A. E. Bergles. 1993. Heat Transfer and Pressure drop Correlations for wisted-tape inserts in Isothermal Tubes. II. Transition and Turbulent Flows, J. Heat Transfer, vol. 115, pp. 890896.

Irvane T. F. and J. P. Hartnett. 1970. Advances in heat transfer, Vol. 6, Academic Press, New York.

Raj M. M. and A. E. Bergles. 2002. Swirl flow heat transfer and pressure drop with twisted-tape inserts, James P. Hartnett and Thomas F. Irvine, Eds., Advances in heat transfer Vol. 36 Academic press Elsevier Science, pp 183-286.

Swapnil D. and G. N. Tiwari. 2008. Thermal modeling of combined system of photovoltaic thermal (PV/T) solar water heater, Journal of Solar Energy, Vol. 82, pp. 602-612.

Watcharin N., E. Smith and P. Pongjet. 2006. Effect of Twisted-tape Inserts on Heat Transfer in a Tube. Paper A-030, The $2^{\text {nd }}$ Joint 
International Conference on " Sustainable Energy and Environmental SEE 2006" 21-23 November 2006, Bangkok, Thailand.

\section{List of Symbols and Abbreviations:}

$\mathrm{A}_{\mathrm{c}}$ Actual flow area, $m^{2}$

$c_{p} \quad$ Fluid specific heat $\mathrm{kJ} / \mathrm{kg} . \mathrm{K}$

$d_{i} \quad$ Tube inner diameter, $m$

$\mathrm{H}$ Twist pitch,

$h_{a v} \quad$ Heat transfer coefficient,

$m$

$\mathrm{I}_{\mathrm{t}} \quad$ Total solar energy per unit collector area

$\mathrm{W} / \mathrm{m}^{2} \mathrm{~K}$

$k \quad$ Fluid thermal conductivity,

$\mathrm{W} / \mathrm{m}^{2}$

L Collector length,

$\mathrm{W} / \mathrm{mK}$

$m$ Mass flow rate,

$m$

$m . \quad$ Fluid flow rate per unit collector area

$\mathrm{kg} / \mathrm{s}$

$q_{u}^{\prime \prime} \quad$ Collector useful energy per unit area

$\mathrm{kg} / \mathrm{m}^{2} . \mathrm{s}$

$\mathrm{W} / \mathrm{m}^{2}$

$\mathrm{T}_{\mathrm{f}, \mathrm{i}} \quad$ Fluid inlet temperature

$\mathrm{K}$

$\mathrm{T}_{\mathrm{f}, \mathrm{o}} \quad$ Fluid exit temperature

$\mathrm{K}$

$u \quad$ Fluid velocity,

$\mathrm{m} / \mathrm{s}$

$u_{a} \quad$ Fluid actual velocity, $\mathrm{m} / \mathrm{s}$

Greek letters

$\begin{array}{lll}\Delta p & \text { Pressure drop, } & \mathrm{Pa} \\ \delta & \text { Twisted-tape thickness, } & \mathrm{m} \\ \mu & \text { Fluid viscosity } & \mathrm{Pa} . \mathrm{s} \\ \rho & \text { Fluid density } & \mathrm{kg} / \mathrm{m}^{3} \\ \text { Subscripts } & & \\ b & \text { Bulk } & \\ w & \text { Wall }\end{array}$

Dimensionless values

$f \quad$ Friction factor

$\mathrm{Nu} \quad$ Nusselt number $=\frac{h d_{i}}{k}$

Pr Prandlt number $=\frac{u c_{p}}{k}$ 
$\operatorname{Re}$

$$
\text { Reynolds number }=\frac{\rho u d_{i}}{\mu}
$$

$\mathrm{R}_{\mathrm{ea}} \quad$ Actual Reynolds number $=\frac{\rho u_{a} d_{i}}{\mu}$

$y \quad$ Ratio of twist pitch to tape thickness $=\frac{H}{\delta}$

$\phi \quad$ Viscosities ratio given by equation 7

$\eta_{c} \quad$ Collector efficiency

\section{Appendix:}

- Air properties equations.

Based on the data tabulated by Duffie J. A. et al. (1974), the curvefitting equations for air properties in the temperature range $270<\mathrm{T}<420$ are as follows;

$$
\begin{array}{ll}
k=-2 * 10^{-8} T^{2}+9 * 10^{-5} T+0.0011 & \mathrm{~W} / \mathrm{m} \mathrm{K} \\
c_{p}=4 * 10^{-7} T^{2}-0.0002 T+1.0304 & \mathrm{~kJ} / \mathrm{kg} \mathrm{K} \\
\rho=\frac{351.69}{T} & \mathrm{~kg} / \mathrm{m}^{3} \\
\mu=\left(-2 * 10^{-6} T^{2}+0.0059 T+0.2492\right) * 10^{-5} & \text { Pa.s }
\end{array}
$$

\section{الملخص العربي}

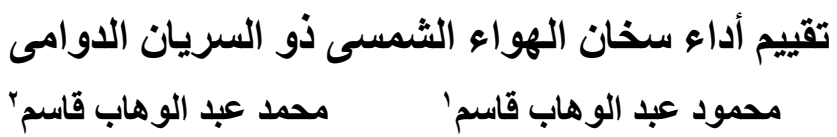

يهدف هذا البحث الى دراسة اداء تصميم جديد لسخان هو اء شمسى. يتم تدويم الهو اء المـار داخل

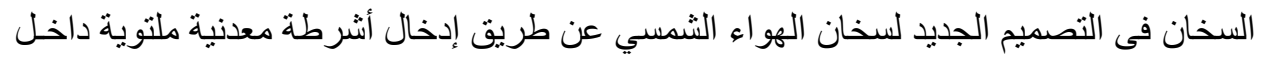

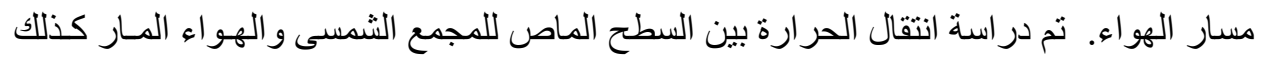

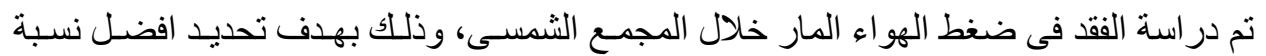

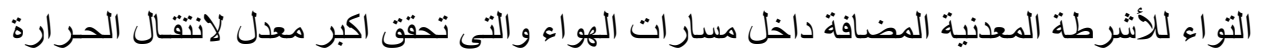

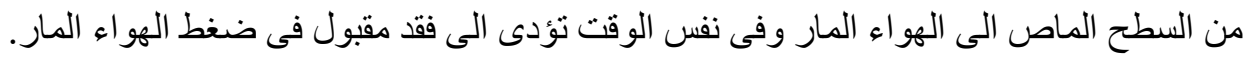

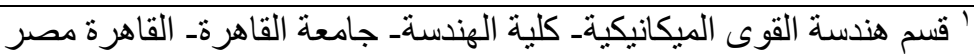

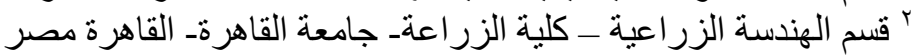


وقد تم تحديد الفقد المقبول فى ضغط الهو اء المار بقيمة مساوية للفقد في ضغط الهو اء المار داخل

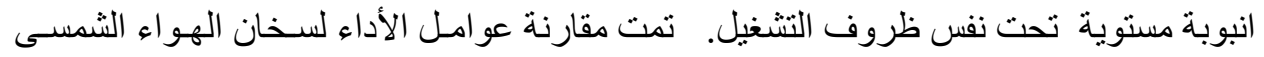

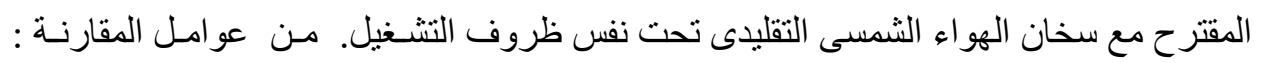

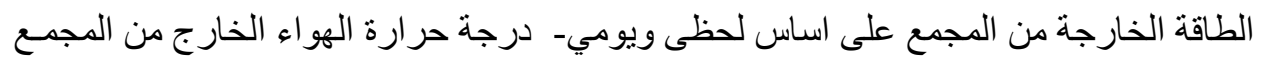
ـالكفاءة اللحظية و اليومية للمجمع الثمسئ

\section{وقد أظهرت أهم النتائج ما يلي:-}

ا. . السخان الثمسي المقترح يتفوق على السخان الثمسي التقليدي لجميع عو امل المقارنـة تحت نفس ظروف التشغيل.

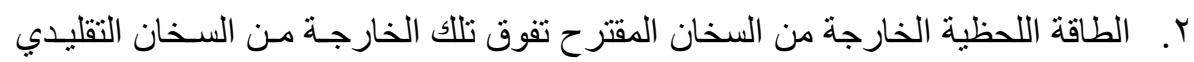

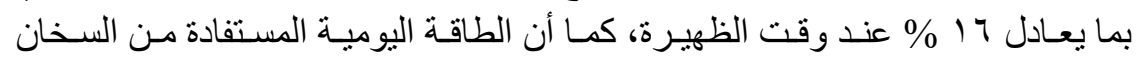

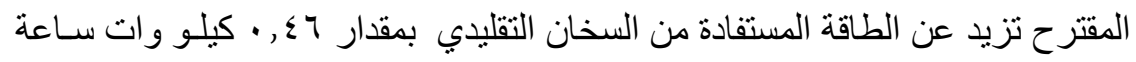

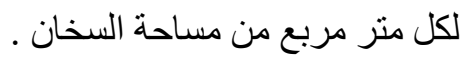

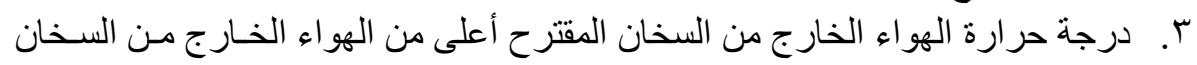

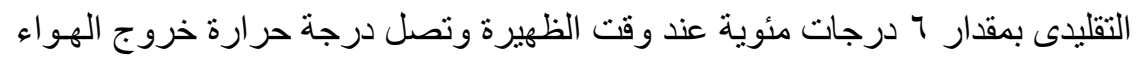

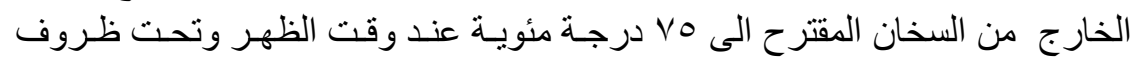

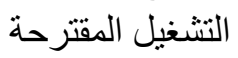

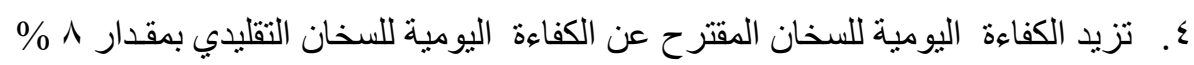
في جميع أيام السنة. 